JURNAL PENJAMINAN MUTU

LEMBAGA PENJAMINAN MUTU

UNIVERSITAS HINDU NEGERI

I GUSTI BAGUS SUGRIWA DENPASAR

Volume 7 Nomor 22021

ISSN : 2407-912X (Cetak)

ISSN : 2548-3110 (Online)

http://ejournal.ihdn.ac.id/index.php/JPM

\title{
KEPERCAYAAN DAN KEPUASAN PENGGUNAAN LMS MAHASISWA SELAMA PEMBELAJARAN DARING
}

\author{
Oleh \\ Teguh Prasetyo ${ }^{1}$, Arita Marini $^{2}$, Mohamad Syarif Sumantri ${ }^{3}$ \\ 1) FKIP Universitas Djuanda Bogor, ${ }^{2) 3}$ Universitas Negeri Jakarta \\ $\underline{\text { teguh@unida.ac.id }}^{1}$, aritamarini@unj.ac.id $^{2}$, syarifsumantri@yahoo.com ${ }^{3}$
}

diterima 29 April 2021, direvisi 17 Mei 2021, diterbitkan 31 Agustus 2021

\begin{abstract}
The implementation of online learning through the Learning Management System (LMS) is universal in higher education. The presentation of learning at the LMS is expected to facilitate student learning during the Covid-19 pandemic. This aims of research to determine the effect of belief in the use of LMS on learning satisfaction in LMS carried out by students. The research approach uses a quantitative type of correlation. This study used a research sample of 101 students. The research instrument is an online questionnaire that has been tested for validity and reliability and is analyzing by regression. The results showed that the regression formulation was: $Y=1.535+0.706$. Is the influence of the belief variable using LMS significant on LMS learning satisfaction? Result of the regression analysis, the significance value of 0.000 is smaller than 0.05 , it can be concluded that belief in the use of LMS affects LMS learning satisfaction. How much trust do the beliefs of LMS affect learning satisfaction at the LMS ( $r$ square), namely $55.8 \%$, while the remaining $44.2 \%$ is another variable and is not researched?. Belief in using LMS on learning satisfaction in LMS is based on aspects of content quality, learning success, ease, and behavior.
\end{abstract}

\section{Keywords: Belief in the use of LMS, Learning management system (LMS), Learning satisfaction}

\section{PENDAHULUAN}

Pandemik Covid-19 yang menyerang semua negara di dunia berdampak pada aspek pendidikan terutama pada proses interaksi pembelajaran pendidik dan peserta didik. Kegiatan pembelajaran yang biasanya dilaksanakan menjadi terganggu baik di tingkat pendidikan dasar, menengah sampai pendidikan tinggi. Semuanya mengalami masalah yang sama yakni terkendala pada interaksi antara pendidik dan peserta didik. Pandemik ini sebenarnya telah direspon oleh para stakeholder dengan melakukan langkahlangkah yang tepat seperti penyediaan fasilitasi pembelajaran yang efektif, komunitas sebagai hubungan empati dengan 
pemangku kepentingan, kreativitas sebagai kemampuan untuk respons yang gesit dan imajinatif, dan konektivitas melalui kesiapan teknologi (Kalloo et al., 2020).

Pemerintah Indonesia sendiri telah mengambil kebijakan untuk melaksanakan pembelajaran dalam jaringan (daring). Kebijakan pemerintah direspon dengan variasi dari masing-masing sekolah menyesuaikan dengan kondisi sekolah, pendidik memodifikasi desain pembelajaran sesuai dengan kondisi dan kebutuhan peserta didik (Arlinwibowo et al., 2020).

Konsep pembelajaran daring ini menjadi salah satu upaya menjalankan pembelajaran jarak jauh agar terhindar dari paparan virus. Pembelajaran jarak jauh pada saat pandemi dapat didesain dengan menerapkan aplikasi sederhana dan tutorial yang jelas dan media pembelajaran dengan aplikasi berbasis Android (Wiratomo \& Mulyatna, 2020). Pembelajaran daring ditingkat pendidikan dasar rata-rata dilakukan oleh guru dengan siswa melalui aplikasi Whatsapp. Bahkan penggunaan aplikasi Whatsapp menjadi bagian penting dalam proses pembelajaran selama pandemi Covid-19 karena aplikasi ini sebagai media penyampaian materi dan tugas yang diselesaikan di rumah (Pertiwi et al., 2020). Sedangkan model pembelajaran daring yang cocok, populer, dan banyak digunakan adalah Learning Management System (LMS) (Rahim \& Razak, 2021; Rhode et al., 2017). LMS di perguruan tinggi bertujuan untuk mendukung dan mengelola pembelajaran secara online agar proses belajar mengajar tetap berjalan dengan baik selama pandemic COVID-19 (Fitriani, 2020). Bahkan penggunaan LMS sudah sangat universal perguruan tinggi baik di Indonesia maupun dunia internasional. Setiap negara telah mengadopsi LMS karena sangat membantu dalam inovasi teknologi pendidikan khusus mendukung pembelajaran online (Rhode et al., 2017).

Learning Management System atau LMS merupakan cara pembelajaran yang banyak menawarkan solusi di tengah-tengah kondisi pandemik Covid-19. LMS menjadi bagian pendekatan paling populer yang digunakan dosen dan mahasiswa, karena proses pembelajaran yang diterapkan dapat menggabungkan pembelajaran tatap muka dan pembelajaran campuran serta meningkatkan kualitas dan kuantitas pembelajaran (Lopes, 2014). LMS merupakan cara terbaik bagi pendidik untuk mengatur, mengelola, dan menyampaikan materi kursus untuk menciptakan pembelajaran yang menarik dan bersahabat bagi peserta didik (Cavus \& Alhih, 2014).

Sistem pelaksanaan pembelajaran LMS melalui edmodo dan moodle dapat memberikan pengalaman bagi guru, administrator, dan siswa (Kakasevski et al., 2008; Triyana et al., 2019) serta dapat dikolaborasikan berbagai metode atau aplikasi media yang mendukung. Misalnya pada penggunaan moodle penggunaan LMS, dipilih karena merupakan perangkat lunak yang open source dan dapat berbasis web di perguruan tinggi (Triyana et al., 2019).

Pembelajaran menggunakan LMS memberikan pengalaman berbeda bagi mahasiswa karena menggunakan platform yang terintegrasi yang mempertimbangkan konten yang akan diajarkan dosen (Conde et al., 2014). Beberapa integrasi pembelajaran di LMS dapat menggunakan blackboard membantu mengembangkan profesional dalam mengajar secara daring (Tawalbeh, 2017), dipadukan dengan Video quipper hasilnya dapat meningkatkan nilai pada pelajaran bahasa Inggris, Matematika, dan Sains peserta didik (Magno, 2017) serta proses integrasi LMS dengan simulasi Phet memberikan pengaruh terhadap keterampilan proses sains (Diana et al., 2018).

Faktor-faktor yang mendukung pengembangan LMS di perguruan tinggi, yakni kegunaanya, kemudahan penggunaan, tujuan penggunaan, perilaku penggunaan aktual, dan efisiensi LMS dalam mendukung proses pembelajaran di universitas (Munir, 2010). Dampak penerapan pembelajaran LMS dapat meningkatkan aspek verbal, figural, numerik dan prosedural untuk melatih mahasiswa sebagai calon guru (Gunawan et al., 2019). Selain itu, kegiatan optimalisasi LMS dapat meningkatkan motivasi belajar, 
efisiensi belajar, dan hasil belajar mahasiswa (Song \& Luan, 2020; Zainal et al., 2021), mengaktifkan interaksi belajar yang dilakukan dosen dan mahasiswa (Holmes \& Elena, 2018). Hal ini menunjukkan bahwa proses pembelajaran LMS dinilai efektif dan efisien. Pada ranah psikologi, variabel resiliensi akademik memiliki pengaruh kesiapan belajar daring yang lebih baik yang kemudian akan meningkatkan kepuasan dalam belajar daring (Kumalasari \& Akmal, 2020).

Hambatan dalam penggunaan LMS ditemukan rasa tidak nyaman mahasiswa dalam mengakses e-learning, akurasi yang kurang, dan tidak adanya kesegeraan jika terjadi kesalahan dalam penggunaan elearning (Larasati \& Andayani, 2019). Sikap tidak nyaman terhadap akses pembelajaran di LMS ini menjadi indikator bahwa ada ketidakpuasan mahasiswa pada penggunaan LMS. Peneliti telah mengumpulkan beberapa penelitian akhir tentang kepuasaan penggunaan LMS di perguruan tinggi sebagai berikut: persepsi kepuasan pengguna dan persepsi penggunaan sistem e-learning (Wagimin et al., 2014); kepuasan penggunaan LMS berpengaruh signifikan terhadap kinerja mahasiswa (Alfan et al., 2014); pengaruh desain dan bahasa terhadap kepuasan user pada sistem pembelajaran E-learning (Christian et al., 2014); media daring mempunyai pengaruh terhadap kepuasan mahasiswa (Hakim \& Mulyapradana, 2020); penerapan aplikasi belajar ini aplikasi Elearning, Edmodo, dan Zoom berdampak signifikan terhadap kepuasan mahasiswa (Rafi et al., 2020). Selanjutnya tingkat kepuasan pembelajaran yang dinilai pada aspek sarana dan prasarana pendukung pembelajaran daring, aktivitas diskusi pembelajaran daring dan pelayanan belajar peserta didik (Nilayani, 2020).

Mahasiswa sebagai pengguna LMS, perlu mendapatkan pelayanan yang maksimal selama menggunakan pembelajaran daring karena jika tidak terlaksana dengan baik maka prestasi belajar mahasiswa menjadi rendah. "Mahasiswa harus terlibat secara langsung karena dapat membuat kepercayaan diri kognitif, kinerja, kontrol mahasiswa, dan kepuasan mahasiswa....pada sistem elearning memiliki hubungan yang signifikan positif dengan prestasi mahasiswa" (Kisanjara et al., 2017). Model pelaksanaan LMS yang efektif dapat diketahui dari kualitas sistem, kualitas kursus, dan kualitas layanan sehingga berdampak pada kepuasaan mahasiswa terhadap penggunaan LMS (Mtebe \& Raisamo, 2014).

Berdasarkan masalah yang telah diuraikan peneliti mendesain penelitian tentang tingkat kepercayaan penggunaan LMS terhadap kepuasaan pembelajaran di LMS. Penelitian ini merupakan lanjutan dari hasil penelitian Yuen et al., (2019) dengan tiga variabel yang diteliti kepercayaan, kepuasan, dan penggunaan LMS oleh mahasiswa. Dimana, Yeun melakukan penelitian dengan model analisis Structural Equation Modeling (SEM) sedangkan pada penelitian bertujuan untuk mengetahui pengaruh kepercayaan penggunaan LMS terhadap kepuasaan pembelajaran di LMS mahasiswa. Adapun hipotesis penelitian yang diajukan: bagaimana pengaruh kepercayaan penggunaan LMS terhadap kepuasaan pembelajaran LMS mahasiswa.

\section{PEMBAHASAN}

Penelitian ini menggunakan metode kuantitatif dengan desain korelasi dengan analisis regresi. Sampel yang digunakan merupakan mahasiswa FKIP Universitas Djuanda Bogor dengan jumlah 101 responden dari kelas reguler dan karyawan. Mahasiswa telah bersedia secara sukarela untuk memberikan data sesuai dengan tujuan penelitian ini. Instrumen mengadaptasi dari hasil penelitian Yuen et al., (2019) dan telah diestimasi validitas dan reliabilitasnya. Validasi dilaksanakan secara empirik variabel X (Kepercayaan Penggunaan LMS) dan nilai koefisien reliabilitas sebesar 0,89 dan koefisien reliabilitas variabel Y (Kepuasan Pembelajaran LMS) sebesar 0,87. Selanjutnya analisis regresi dibantu dengan aplikasi SPSS versi 21 untuk windows.

Berdasarkan hasil penelitian tentang kepercayaan penggunaan LMS terhadap 
kepuasan pembelajaran di LMS. Pada tingkat kepercayaan penggunaan LMS menurut mahasiswa rata-rata mencapai kategori tinggi yakni menyentuh angka $82,2 \%$. Bahkan mahasiswa tidak ada yang memiliki tingkat kepercayaan rendah. Kategori kepuasan LMS menurut mahasiswa berada pada kategori sedang yakni sebesar 70,3\%.

Hasil uji asumsi normalitas dilakukan dengan Kolmogorof Smirnof menunjukkan bahwa nilai dari signifikansi (2-tailed) kepercayaan penggunaan LMS dengan kepuasan LMS sebesar 0,939 dan lebih besar dari 0,05 yang menyatakan data normal. Pada uji linieritas digunakan untuk mengetahui apakah variabel kepercayaan penggunaan LMS dengan kepuasan pembelajaran di LMS memiliki hubungan yang linier dihasilkan pada variabel kepercayaan penggunaan LMS dengan signifikansi sebesar $0,000<0,05$ dan kepuasan pembelajaran di LMS adalah 0,000 $<0,05$. Hasil luaran tersebut membuktikan bahwa kepercayaan penggunaan LMS dan kepuasan pembelajaran di LMS memiliki hubungan yang linier.

Berdasarkan hasil analisis data persamaan regresi yang dihasilkan formulasi: $\mathrm{Y}=1.535$ $+0,706$. Hal ni menunjukkan bahwa nilai koefisien konstanta (a) pada variabel kepercayaan penggunaan LMS tidak ada atau 0 maka nilai konsisten kepuasan pembelajaran di LMS sebesar 1.535. Selanjutnya angka koefisen regresi menunjukkan 0,706 , yang berarti setiap ada penambahan $1 \%$ maka nilai kepuasan pembelajaran di LMS akan meningkat sebesar 0706.

Data pengujian hipotesis statistik yang digunakan untuk mengetahui apakah pengaruh dari variabel kepercayaan penggunaan LMS signifikan terhadap kepuasan pembelajaran LMS. Hasil dari analisis regresi sederhana nilai signifikansi 0,000 lebih kecil dari 0,05 yang bermakna $\mathrm{H} 0$ ditolak sedangkan Ha diterima. Hal ini dapat disimpulkan bahwa bahwa kepercayaan penggunaan LMS berpengaruh terhadap kepuasan pembelajaran LMS. Besar pengaruh (R-square) kepercayaan penggunaan LMS berpengaruh terhadap kepuasan pembelajaran di LMS sebesar 0,558 atau 55,8\% sedangkan sisanya sebesar $44,2 \%$ merupakan variabel yang tidak diteliti.

Penelitian ini telah membuktikan bahwa kepercayaan penggunaan LMS mahasiswa memiliki pengaruh terhadap kepuasan pembelajaran di LMS sebesar 55,8\%. Pada hakikatnya mahasiswa memiliki data kepercayaan yang tinggi secara deskriptif yakni, sebesar $82 \%$ yang berarti bahwa mahasiswa meyakini bahwa LMS yang ada mampu memberikan fasilitas belajar yang sangat baik dan memadai. LMS harus mempertimbangkan aspek keterampilan, ekonomi, manajemen universitas, literasi TK, panduan dan gambaran kinerja LMS, kualitas konten, dan penggunaan LMS (Mohammadi et al., 2021; Rahim \& Razak, 2021).

Kepercayaan penggunaan LMS pada penelitian ini berdasarkan aspek kualitas konten, keberhasilan belajar, kemudahan dan perilaku. Senada dengan temuan yang disampaikan oleh Eom, (2014) bahwa kepuasan pengguna LMS dapat dilihat pada dua aspek yakni kualitas informasi yang ada di LMS dan kesiapan untuk pembelajaran daring. Mahasiswa mengharapkan LMS yang digunakan dapat selalu relevan dengan informasi materi kuliah, mudah dipahami, dan up to date sedangkan aspek yang lain adalah kesiapan mahasiswa dalam pembelajaran di LMS seperti komputer, laptop, internet, email, dan handhopne (Eom, 2014). Pembelajaran di LMS harus mendukung TI yang dirasakan, interaktivitas, dan teknologi yang tepat sehingga mahasiswa setia menggunakan LMS (Janson et al., 2017).

Kepercayaan penggunaan LMS mahasiswa diukur aspek keberhasilan belajar sehingga mahasiswa merasa bahwa penggunaan LMS akan berdampak pada hasil dan prestasi belajar. Hasil riset juga mendukung bahwa mahasiswa memiliki kepercayaan dalam menggunakan pembelajaran di LMS agar meningkatkan hasil belajar peserta didik ((Diana et al., 2018), pemahaman konten belajar dan motivasi (Bibi \& Jati, 2015), serta meningkatkan umpan balik (Shakerian et al., 2021). Bahkan yang menjadi tinggi 
kepercayaan mahasiswa dalam pembelajaran di LMS adalah nilai hasil belajar (Shayan \& Iscioglu, 2017). Pada penelitian ini belum diukur capaian hasil belajar mahasiswa karena pengambilan data kegiatan perkuliahan masih berlangsung di pertengahan semester genap tahun akademik 2020/2021. Hal ini juga menjadi keterbatasan dalam artikel penelitian ini.

Mahasiswa selalu mempertimbangkan kepercayaan pembelajaran di LMS berdasarkan aspek kemudahan. Mahasiswa memiliki kepercayaan bahwa dari kelas atau kursus daring harus menyediakan konten materi belajar secara berurutan, kemudahan dalam menyelesaikan tugas, dan kepraktisan dalam melihat dan membaca konten yang ada di LMS (Xu \& Mahenthiran, 2016). Mahasiswa tertarik pada penggunaan LMS karena percaya bahwa pembelajaran di LMS, dirasakan dapat membantu dan mendukung kegiatan akademik seperti mengerjakan tugas, membaca materi kembali, dan memberikan komentar yang ada di LMS (Juhary, 2014)). Sebaiknya kualitas layanan konten pembelajaran LMS yang disediakan dosen dan instruktur meliputi informasi perkuliahan, konten materi belajar kuliah dan hal-hal yang mendukung proses pembelajaran mahasiswa (Ohliati \& Abbas, 2019) serta kemudahan dalam navigasi, mudah diakses, dan responsif dari pengajar (Naveh et al., 2012).

Kepercayaan berdasarkan aspek perilaku mahasiswa penting diperhatikan dalam pembelajaran di LMS. Perilaku ini meliputi kegiatan untuk mengerjakan tugas dan ujian, mengunggah makalah, menyelesaikan tugas secara daring. Hal yang sama juga disampaikan Ain et al., (2015) bahwa niat belajar mahasiswa, ekspektasi kinerja, pengaruh sosial, kondisi fasilitas LMS dan niat perilaku mahasiswa berdampak pada penggunaan LMS. Mahasiswa mempertimbangkan aspek perilaku sebagai bentuk kepercayaan terhadap kepuasaan pembelajaran di LMS.

Kepercayaan yang tinggi seringkali menghadapi masalah pada saat mahasiswa menggunakan LMS, seperti gangguan akses LMS yang berhenti/tidak dapat diakses, tidak stabil, LMS lambat, dan internet yang tidak memadai (Juhary, 2014). Sedangkan bagi dosen lebih kepada bagaimana menyiapkan konten belajar dan proses belajar dapat digunakan secara maksimal. Mahasiswa yang mengalami masalah dan kendala saat pembelajaran di LMS dapat mengakibatkan kepuasaan pembelajaran di LMS menjadi rendah. Oleh karena itu, penggunaan LMS harus berpusat pada mahasiswa namun dibarengi dengan pengembangan keterampilan dosen dalam menggunakan LMS sehingga dicapai kursus yang lebih baik an mengembangkan keterampilan berpikir mahasiswa (Kamarga, 2018).

Hasil penelitian secara empirik dapat membuktikan bahwa kepercayaan penggunaan LMS sangat berpengaruh pada penggunaan pembelajaran di LMS. Walaupun angka mencapai $55,8 \%$ pengaruhnya namun perbaikan pembelajaran harus dilakukan baik oleh perguruan tinggi yang bersangkutan (FKIP Universitas Djuanda Bogor) dan para dosen. Tantangan para dosen untuk menggunakan pembelajaran daring yakni bagaimana mengukur perkembangan belajar mahasiswa ketika daring, apa yang dirasakan ketika melaksanakan pembelajaran daring, dan nilai kemanfaatan bagi para mahasiswa ketika pembelajaran daring di LMS (Santiago et al., 2020).

Pembelajaran di LMS harus memperhatikan hal-hal penting seperti aspek kualitas untuk memastikan kepuasan konsumen, yakni mahasiswa (Rahim \& Razak, 2021). Oleh karena itu, pembelajaran mahasiswa harus disiapkan secara terencana dan sistemati agar menghasil proses dan hasil belajar yang maksimal. Selain itu juga, layanan pembelajaran di LMS ini akan memberikan alternatif dosen dan mahasiswa ketika tidak bisa melaksanakan pembelajaran tatap muka maka dapat diselenggarakan melalui LMS yang berbasis Website baik dengan sajian pembelajaran campuran maupun pembelajaran daring penuh (Prasetyo et al., 2016).

Penelitian ini masih memiliki keterbatasan yakni, belum mengukur hasil belajar mahasiswa selama pembelajaran 
daring di LMS dan jumlah sampel merupakan kelas yang diajar penulis. Penelitian selanjutnya, dapat difokuskan pada penelitian kualitatif atau penelitian eksperimen dengan mengukur hasil belajar mahasiswa.

\section{KESIMPULAN}

Kepercayaan penggunaan sangat berpengaruh terhadap kepuasaan pembelajaran di LMS di perguruan tinggi. Mahasiswa selalu memberikan kepercayaan tinggi tentang pelaksanaan pembelajaran daring di LMS namun harus ditingkatkan kualitas konten, layanan, dan sistem sehingga makin tinggi kepercayaan dan kepuasaan mahasiswa pada pelaksanaan pembelajaran di LMS. Peran pimpinan perguruan tinggi dan para dosen untuk terus meningkatkan aspekaspek yang mendukung kepuasan pembelajaran di LMS sangat dibutuhkan.

\section{DAFTAR PUSTAKA}

Ain, N. U., Kaur, K., \& Waheed, M. (2015). The influence of learning value on learning management system use: An extension of UTAUT2. Information Development, 1-16. https://doi.org/10.1177/0266666915 597546

Alfan, Z., Astuti, E. S., \& Riyadi. (2014). MODEL KEBERHASILAN BELAJAR MAHASISWA MENGGUNAKAN LEARNING MANAGEMENT SYSTEM (Studi pada Mahasiswa S1 Program Teknologi Informasi dan Ilmu Komputer Universitas Brawijaya Angkatan 2012). Jurnal Administrasi Bisnis S1 Universitas Brawijaya, 14(2), 84459.

Arlinwibowo, J., Retnawati, H., Kartowagiran, B., \& Kassymova, G. K. (2020). Distance learning policy in Indonesia for facing pandemic COVID-19: School reaction and lesson plans. Journal of Theoretical and Applied Information Technology, 98(14), 2828-2838.

Bibi, S., \& Jati, H. (2015). Efektivitas model blended learning terhadap motivasi dan tingkat pemahaman mahasiswa mata kuliah algoritma dan pemrograman. Jurnal Pendidikan Vokasi, 5(1), 74. https://doi.org/10.21831/jpv.v5i1.60 74

Cavus, N., \& Alhih, M. S. (2014). Learning Management Systems Use in Science Education. Procedia - Social and Behavioral Sciences, 143(February 2014), 517-520. https://doi.org/10.1016/j.sbspro.2014 .07 .429

Christian, L., Permatasari, A., \& Sugandi, L. (2014). Terhadap Kepuasan User Dalam Proses Belajar Mengajar Pada Universitas Di Jakarta. 776 ComTech, 5(2), 775-785.

Conde, M. Á., García-Peñalvo, F. J., Rodríguez-Conde, M. J., Alier, M., Casany, M. J., \& Piguillem, J. (2014). An evolving Learning Management System for new educational environments using 2.0 tools. Interactive Learning Environments, 22(2), 188-204. https://doi.org/10.1080/10494820.20 12.745433

Diana, N., Walidain, S. N., \& Rahman, A. H. (2018). Integrasi Learning Management System ( LMS ) dan Simulasi PhET pada Pembelajaran Fisika Terhadap Keterampilan Proses Sains. QUARK: Jurnal Inovasi Pembelajaran Fisika Dan Teknologi, 1(1), 36-40.

Eom, S. B. (2014). Understanding e-learners' satisfaction with learning management systems. Bulletin of the Technical Committee on Learning Technology, 16(2-3), 10-13.

Fitriani, Y. (2020). Analisa Pemanfaatan Learning Management System (Lms) Sebagai Media Pembelajaran Online Selama Pandemi Covid-19. Journal of Information System, Informatics and Computing, 4(2), 1-8.

Gunawan, G., Sahidu, H., Susilawati, S., Harjono, A., \& Herayanti, L. (2019). Learning Management System with 
Moodle to Enhance Creativity of Candidate Physics Teacher. Journal of Physics: Conference Series, 1417(1), 0-6. https://doi.org/10.1088/17426596/1417/1/012078

Hakim, M., \& Mulyapradana, A. (2020). Pengaruh Penggunaan Media Daring dan Motivasi Belajar Terhadap Kepuasan Mahasiswa Pada Saat Pandemik Covid-19. Widya Cipta: Jurnal Sekretari Dan Manajemen, 4(2), 154-160. https://doi.org/10.31294/widyacipta. v4i2.8853

Janson, A., Leimeister, J. M., \& Sollner, M. (2017). Individual Appropriation of Learning Management SystemsAntecedents and Consequences. Transactions on Human - Computer Interaction Research, 9(3), 173-201.

Juhary, J. (2014). Perceived usefulness and ease of use of the learning management system as a learning tool. International Education Studies, 7(8), 23-34. https://doi.org/10.5539/ies.v7n8p23

Kakasevski, G., Mihajlov, M., Arsenovski, S., \& Chungurski, S. (2008). Evaluating usability in learning management system moodle. Proceedings of the International Conference on Information Technology Interfaces, ITI, May 2014, 613-618. https://doi.org/10.1109/ITI.2008.458 8480

Kalloo, R. C., Mitchell, B., \& Kamalodeen, V. J. (2020). Responding to the COVID19 pandemic in Trinidad and Tobago: challenges and opportunities for teacher education. Journal of Education for Teaching, 46(4), 452462.

https://doi.org/10.1080/02607476.20 20.1800407

Kamarga, H. (2018). Constructing Online Based History Learning: Comparison of Learning Content Management System (LVCMS) To Learning Management System (LMS).
Historia: Jurnal Pendidik Dan Peneliti Sejarah, 12(2), 255. https://doi.org/10.17509/historia.v12 i2. 12105

Kisanjara, S., Tossy, T., Sife, A., \& Msanjila, S. (2017). An Integrated Model for Measuring the Impacts of E-Learning on Students' Achievement in Developing Countries. International Journal of Education and Development Using Information and Communication Technology, 13(3), 109-127.

Kumalasari, D., \& Akmal, S. Z. (2020). Resiliensi akademik dan kepuasan belajar daring di masa pandemi COVID-19: Peran mediasi kesiapan belajar daring. Persona:Jurnal Psikologi Indonesia, 9(2), 353-368. https://doi.org/10.30996/persona.v9i 2.4139

Larasati, N. A., \& Andayani, S. (2019). Pengaruh Penggunaan Learning Management System (LMS) Terhadap Tingkat Kepuasan Mahasiswa Menggunakan Metode DeLone and McLean. Jurnal Teknik Informatika UNIKA Santo Thomas, 4(1), 13-20.

Lopes, A. P. (2014). Mobile Learning Management Systems in Higher Education. Virtual Learning Environments, July 2014, 12491264. https://doi.org/10.4018/978-14666-0011-9.ch608

Magno, C. (2017). Facilitating Student Learning in Schools through a Learning Management System: An Action Research. The International Journal of Research and Review, 12(April).

Mohammadi, M. K., Mohibbi, A. A., \& Hedayati, M. H. (2021). Investigating the challenges and factors influencing the use of the learning management system during the Covid-19 pandemic in Afghanistan. In Education and Information Technologies (Issue 0123456789). Springer

US. 
https://doi.org/10.1007/s10639-02110517-z

Mtebe, J. S., \& Raisamo, R. (2014). A model for assessing learning management system success in higher education in sub-saharan Countries. Electronic Journal of Information Systems in Developing Countries, 61(1). https://doi.org/10.1002/j.16814835.2014.tb00436.x

Munir, M. (2010). Penggunaan Learning Management System (Lms) Di Perguruan Tinggi: Studi Kasus Di Universitas Pendidikan Indonesia. Jurnal Cakrawala Pendidikan, 1(1), 109-119. https://doi.org/10.21831/cp.v1i1.222

Naveh, G., Tubin, D., \& Pliskin, N. (2012). Student Satisfaction with Learning Management Systems: A lens of critical. Technology, Pedagogy and Education, 21(3), 337-350. https://doi.org/10.1080/1475939X.2 012.720413

Nilayani, S. A. P. (2020). Survei Kepuasan Siswa Terhadap Proses Belajar Daring Selama Pandemi Covid-19. Cetta: Jurnal Ilmu Pendidikan, 3(3), 453-462.

http://jayapanguspress.penerbit.org/i ndex.php/cetta

Ohliati, J., \& Abbas, B. S. (2019). Measuring students satisfaction in using learning management system. International Journal of Emerging Technologies in Learning, 14(4), 180-189. https://doi.org/10.3991/ijet.v14.i04.9 427

Pertiwi, N., Saud, U. S., \& Saffitri, Y. N. V. (2020). Utilization of the WhatsAppBased Internet for Elementary School Students during the Covid-19 Pandemic. The 3rd International Conference on Elementary Education (ICEE 2020), 3(November), 126-132.

Prasetyo, T., Widyasari, \& Hartono, R. (2016). Pengembangan Inovasi Pendidikan Melalui Blended Learning. Didaktika Tauhidi, 4(2).
Rafi, I., Nurjannah, F. F., Fabella, I. R., \& Andayani, S. (2020). Peluang dan Tantangan Pengintegrasian Learning Management System (LMS) dalam Pembelajaran Matematika di Indonesia. Jurnal Tadris Matematika, 3(2), 229-248. https://doi.org/10.21274/jtm.2020.3. 2.229-248

Rahim, R. B. A., \& Razak, F. Z. A. (2021). The impact of system quality on satisfaction to use learning management system: E-campus perspective. Journal of Physics: Conference Series, 1793(1). https://doi.org/10.1088/17426596/1793/1/012021

Rhode, J., Richter, S., Gowen, P., Miller, T., \& Wills, C. (2017). Understanding faculty use of the learning management system. Online Learning Journal, 21(3), 68-86. https://doi.org/10.24059/olj.v\%vi\%i. 1217

Santiago, B. J., Ramírez, J. M. O., RodríguezReséndiz, J., Dector, A., García, R. G., González-Durán, J. E. E., \& Sánchez, F. F. (2020). Learning management system-based evaluation to determine academic efficiency performance. Sustainability (Switzerland), 12(10), $1-17$. https://doi.org/10.3390/su12104256

Shakerian, S., Noori, S., Hiedarpoor, P., Shams, L., \& Hosseinzadeh, M. (2021). Developing a Web-Based Learning Management System (LMS) for Master's Thesis Process in the Shahid Beheshti University of Medical Sciences. Journal of Medical Education, 19(4), 1-9. https://doi.org/10.5812/jme.110696

Shayan, P., \& Iscioglu, E. (2017). An Assessment of Students' Satisfaction Level from Learning Management Systems: Case Study of Payamnoor and Farhangian Universities. Engineering, Technology \& Applied Science Research, 7(4), 1874-1878. 
https://doi.org/10.48084/etasr.1041

Song, Y. N., \& Luan, Z. Q. (2020). Function

Design Optimization of Learning Management System (LMS) Based on Student Perspective-Case Study of Canvas Application University of Colorado Denver. Journal of Physics: Conference Series, 1621(1). https://doi.org/10.1088/17426596/1621/1/012058

Tawalbeh, T. I. (2017). EFL Instructors'

Perceptions of Blackboard Learning Management System (LMS) at University Level. English Language Teaching, 11(1), 1. https://doi.org/10.5539/elt.v11n1p1

Triyana, I. G. N., Sri Ratmini, N. K., Mandra, I. W., \& Ruscitadewi, N. W. (2019). The Use Of Moodle-Based ELearning In Evaluating Students' Learning. Jurnal Penjaminan Mutu, $5(2)$, 165. https://doi.org/10.25078/jpm.v5i2.10 89

Wagimin, I., Patni Ninghardjanti, \& Kristiani. (2014). Model Kesuksesan Pembelajaran Dengan E-Learning Di Perguruan Tinggi. Jurnal Penelitian Pendidikan INSANI, 16(1), 23-35.

Wiratomo, Y., \& Mulyatna, F. (2020). Use of
Learning Management Systems in Learning Efforts during a Pandemic. Journal of Mathematical Pedagogy (JoMP), 1(2), 62-71.

Xu, H., \& Mahenthiran, S. (2016). Factors that Influence Online Learning Assessment and Satisfaction: Using Moodle as a Learning Management System. International Business Research, $9(2), \quad 1$. https://doi.org/10.5539/ibr.v9n2p1

Yuen, A. H. K., Cheng, M., \& Chan, F. H. F. (2019). Student satisfaction with learning management systems: A growth model of belief and use. British Journal of Educational Technology, 50(5), 2520-2535. https://doi.org/10.1111/bjet.12830

Zainal, A., Tampubolon, T. A. M., Herliani, R., \& ... (2021). ... Pembelajaran Daring (SIPDA) as an Online Learning Management System on Learning Outcomes of Financial Accounting Subject: A Mediation Effect of Learning .... ... on Strategic Issues ..., 163(ICoSIEBE 2020), 327-331. https://www.atlantispress.com/proceedings/icosiebe20/125953011 